\title{
The influence of perioperative factors on outcomes in children aged less than 18 months after repair of tetralogy of Fallot
}

\author{
Elisabeth I. van Dongen, $\mathrm{MD}^{\mathrm{a}}$ \\ Angelique G. Glansdorp, $\mathrm{MD}^{\mathrm{a}}$ \\ Reinout J. Mildner, $M^{\mathrm{a}}$ \\ Brian W. McCrindle, MD, MPH, FACC ${ }^{b}$ \\ Andreas G. Sakopoulos, MD ${ }^{\mathrm{c}}$ \\ Glen VanArsdell, MD' \\ William G. Williams, MD ${ }^{\mathrm{c}}$ \\ Desmond Bohn, $\mathrm{MB}, \mathrm{BCh}^{\mathrm{a}}$
}

From the Department of Critical Care Medicine $^{\mathrm{a}}$ and the Divisions of Cardiology ${ }^{\mathrm{b}}$ and Cardiovascular Surgery, ${ }^{\mathrm{c}}$ The Hospital for Sick Children, Toronto, Ontario, Canada

Received for publication June 18, 2002; revisions requested July 22, 2002; revisions received Aug 7, 2002; accepted for publication Aug 27, 2002.

Address for reprints: Dr Desmond Bohn, The Department of Critical Care Medicine, The Hospital for Sick Children, Toronto, Ontario, M5G 1X8 Canada (E-mail: dbohn@ sickkids.on.ca).

J Thorac Cardiovasc Surg 2003;126:703-10

Copyright () 2003 by The American Association for Thoracic Surgery

0022-5223/2003\$30.00+0

doi:10.1016/S0022-5223(03)00035-7
Objectives: To determine the impact of age at repair in patients with tetralogy of Fallot on early postoperative morbidity.

Methods: All patients less than 19 months of age (median age, 8 months; range, 36 days-18.5 months) who underwent complete repair of tetralogy of Fallot between January 1997 and December 1999 were reviewed. Data were analyzed on the preoperative clinical and anatomical characteristics, operative procedure and postoperative course in the intensive care unit. Independent factors associated with intensive care unit stay were sought using Cox's proportionate hazard modeling. In addition, independent factors associated with an intensive care unit stay of more than 2 days were sought in multiple logistic regression analysis.

Results: Seventy-eight patients underwent surgical repair; 3 had (4\%) had a previous systemic to pulmonary arterial shunt. There was no operative mortality. One late death occurred. The median intensive care unit length of stay and mechanical ventilation time were 2 days (range, 1-14) and 16.2 hours (range, 0-267), respectively. Age less than 3 months was associated with increased use of vasoactive drugs, higher postoperative fluid requirement, and a higher incidence of organ dysfunction but no patient required renal replacement therapy. The duration of ventilator support and the intensive care unit length of stay were also longer in this age group.

Conclusions: Primary repair at an early age has excellent short-term outcome. Patients less than 3 months of age have an increased but transient intensive care unit morbidity.

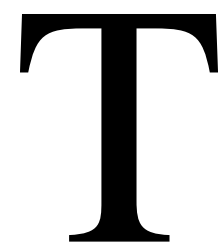

he traditional approach to the management of cyanotic infants with tetralogy of Fallot (TOF) has been the placement of a systemic to pulmonary artery (Blalock-Taussig) shunt followed by a complete repair after the first 6 months of life. Improvements in cardiopulmonary bypass technology, better myocardial protection, and the introduction of modified ultrafiltration have led to an increasing trend to perform a surgical correction both in cyanotic and acyanotic infants in the first few months of life. ${ }^{1-15}$ The rationale for this approach is that the early relief of right ventricular outflow tract obstruction will result in less right ventricle (RV) hypertrophy, the avoidance of necessity of an outflow patch leading to less pulmonary valve incompetence, which has been associated with an increased incidence of late 
sudden death. ${ }^{16}$ In addition, the pulmonary artery distortion that frequently occurs with the placement of a shunt may result in morbidity and mortality. ${ }^{17-19}$ However, advocates of the traditional approach would argue that performing a complete repair in small infants still carries an increased morbidity and mortality risk compared to delayed repair at an older age.

At the Hospital for Sick Children, the surgical approach to the management of tetralogy has evolved over the past decade from the traditional palliation and later correction to one of primary repair in the first few months of life. The current institutional policy is now elective repair at 6 months for those infants who are not having cyanotic spells and repair rather than shunting for spelling infants less than 6 months of age. We have previously published our experience in the management of patients with TOF (years 1987-1994) who were less than 18 months of age at the time of surgical repair. That study, in which the median age at repair was 13 months, focused on perioperative issues that might impact on clearly defined short-term outcomes and showed that younger age at repair and previous palliation were correlated with increased intensive care unit (ICU) length of stay. ${ }^{20}$ However, only $9 / 89$ patients were less than 6 months of age at the time of repair. We have undertaken a second study to evaluate impact of a change in institutional policy that evolved between 1994 and 1997 to earlier correction in the first few months of life. We focused our review on the early postoperative morbidity and mortality.

\section{Methods \\ Patient Population}

Following institutional review board approval, all patients with TOF who underwent repair between January 1997 and December 1999 at The Hospital for Sick Children were identified from cardiology, cardiac surgery, and ICU databases. Patients who were older than 19 months of age at the time of repair, and those with associated absent pulmonary valve, atrioventricular septic defect or pulmonary atresia were excluded. Patients who had a BlalockTaussig shunt, additional ventricular septal defects (VSD), an associated atrial septal defect (ASD), or coronary artery abnormality were included.

In the period of study, 81 patients were identified. Hemodynamic data were missing on 3 patients, so the study group consisted of 78 patients, of whom 41 were female $(53 \%)$ and 37 were male $(47 \%)$. The median age at repair was 8 months (range, 36 days-18.5 months) with a median weight of $7.2 \mathrm{~kg}$ (range, 2.8-12). The spectrum of age ranges were less than 3 months $(n=12), 3$ to less than 6 months $(n=20), 6$ to less than 9 months $(n=21)$, and older than 9 months $(\mathrm{n}=25)$.

\section{Preoperative Data}

Anatomical characteristics such as main and branch pulmonary artery (PA) stenosis, additional VSDs, patent foramen ovales (PFOs), and ASDs, systemic to pulmonary collaterals, and coronary arterial abnormalities were defined by preoperative echocar- diography. Furthermore, it was noted if patients were cyanotic or were receiving propranolol. The presence of other cardiac and noncardiac abnormalities was also noted.

\section{Operative Characteristics}

The following details of the surgical repair were documented; the approach to the repair of the VSD and the RV outflow tract obstruction, whether the pulmonary valve was spared from disruption or a transannular patch with or without a pericardial monocusp valve was used and whether a PA arterioplasty was done. The cardiopulmonary bypass time and aortic crossclamp time were also recorded. Data were also collected on intraoperative hemodynamic pressure and saturation measurements as well as the findings on intraoperative echocardiography.

\section{Postoperative ICU Data}

Data were collected on the ICU length of stay, duration of mechanical ventilation, and complications including arrhythmias, chest radiograph changes, infections, and diaphragmatic paresis. Patients are generally discharged from the ICU the day following extubation. In order to quantify the postoperative morbidity in terms of extrathoracic organ dysfunction, a pediatric modification of the multiple organ dysfunction syndrome (MODS) score was used. ${ }^{21}$ This quantifies the failure of the main organ systems by means of age-adjusted criteria, which are based on clinical or laboratory measurements and supportive therapies (Table 1). Criteria for an infection were the presence of elevated white blood cell count, a positive culture and clinical symptoms including fever above $38.5^{\circ} \mathrm{C}$.

Hemodynamic data measurements at 1, 2, 4, 8, 12, 16, 20, 24, 36 , and 48 hours after repair including heart rate, central venous pressure, left atrial pressure, and systemic arterial pressure (systolic, diastolic, and mean) were reviewed. In addition, at identical time points lactate and mixed venous oxygen saturation and the arterial acid-base status and blood gases were recorded. The use and duration of intravenous inotropic and vasodilatory agents, both specified by name, were noted and the dose was recorded at the same 10 time points as described above. Reduced glucose levels $(<4 \mathrm{mmol} / \mathrm{L})$ during the total period of ICU stay were also noted. Data were also collected on need for reintervention and/or death within 30 days of surgery. Patients were followed up until the time of hospital discharge.

\section{Data Analysis}

Data are described as frequencies, medians with ranges, and means with standard deviations. Where there are missing data, the number of nonmissing values is given. Time to discharge from the ICU was represented by Kaplan-Meier estimates. Independent factors associated with time to ICU discharge were sought using Cox's proportionate hazard modeling. In addition, independent factors associated with an ICU stay of more than 2 days were sought in multiple logistic regression analysis. After a normalizing transformation (natural logarithm), independent factors associated with duration of mechanical ventilation were sought in general linear regression modeling. Trends related to age were sought by categorizing age at repair into 4 groups: $<3$ months, 3 to 5 months, 6 to 8 months, and 10 to 18 months. Age-related trends in preoperative and operative characteristics were sought with $\chi^{2}$, Mantel- 
Haenszel $\chi^{2}$, analysis of variance, and Kruskal-Wallis analysis of variance as appropriate. The relationships to age at repair and postoperative time to hemodynamic parameters were sought in mixed linear regression analysis for repeated measures. All analyses were performed using SAS Version 7 statistical software (SAS Institute, Inc., Cary, NC) with default settings except where indicated.

\section{Results}

Total Patient Population

Preoperative data and associated anomalies. Fortytwo patients had previous tetralogy spells (54\%), 56 were cyanotic $(72 \%)$, and 43 were receiving propranolol $(55 \%)$. Three patients had a previously placed BT shunt (4\%), 2 at other institutions prior to referral for repair (age 5 months and 12 days). In the third patient, the smallest in this series $(2.8 \mathrm{~kg})$, the decision to perform a shunt rather than a repair was based on the size of the pulmonary arteries $(3 \mathrm{~mm})$. This infant subsequently underwent successful repair at 39 days of life after the shunt blocked.

Apart from the typical features of tetralogy, the significant preoperative echocardiographic findings were systemic to pulmonary artery collaterals in 20 patients $(26 \%)$ and coronary arterial abnormalities in 10 patients (13\%). These consisted of the presence of an accessory left anterior descending coronary artery from the right coronary artery in 9 cases and 1 case of a coronary fistula. Associated intrathoracic vascular abnormalities were noted in 27 patients (35\%), including right aortic arch in 22 patients, left superior vena cava to coronary sinus drainage in 4 , and aberrant subclavian artery in 4. Chromosomal abnormalities and malformation syndromes were found in 17 patients $(22 \%)$. These included 6 patients with Down syndrome, 3 patients with diGeorge syndrome, 2 patients with VACTER(L)* association, and 1 patient with $\mathrm{CHARGE}^{\dagger}$ association.

\section{Operative Characteristics}

The operative approach to closure of the VSD $(n=76)$ was through the atrium in 67 patients $(88 \%)$ and through a ventriculotomy in $9(12 \%)$. The RV outflow tract was repaired by the transatrial approach in 9 patients (12\%), via a transatrial-transpulmonary approach in $62(79 \%)$, through the ventricular infundibulum in $53(68 \%)$, and through the pulmonary valve annulus in 22 patients $(28 \%)$. Sometimes different approaches were combined in the same patient. The pulmonary valve was spared (not disrupted) during repair in 50 patients $(64 \%)$, a transannular patch was used in $15(19 \%)$, and a transannular patch with placement of a pericardial monocusp valve was used in 13 patients $(17 \%)$. A PA arterioplasty was performed in 72 patients (92\%). The

\footnotetext{
* Vertebral defects, anal atresia, tracheo-esophageal fistula, and radial hypoplasia.

${ }^{\dagger}$ Coloboma, heart disease, atresia choanae, retarded growth, genito-urinary abnormalities, and ear anomalies.
}

TABLE 1. Criteria for failure of specific organ systems

\begin{tabular}{|c|c|}
\hline Organ system & Criteria for organ system failure \\
\hline \multirow[t]{6}{*}{ Cardiovascular } & $\begin{array}{l}\text { Mean arterial blood pressure }<40 \mathrm{~mm} \mathrm{Hg} \\
\quad \text { (infants }<12 \mathrm{mo} \text { ) }\end{array}$ \\
\hline & $\begin{array}{l}\text { Mean arterial blood pressure }<50 \mathrm{~mm} \mathrm{Hg} \\
\text { (children } \geq 12 \mathrm{mo} \text { ) }\end{array}$ \\
\hline & Heart rate $<50$ beats/min (infants $<12 \mathrm{mo}$ ) \\
\hline & Heart rate $<40$ beats/min (children $\geq 12 \mathrm{mo}$ ) \\
\hline & Cardiac arrest \\
\hline & $\begin{array}{l}\text { Continuous vasoactive drug infusion for } \\
\text { hemodynamic support }\end{array}$ \\
\hline \multirow[t]{7}{*}{ Respiratory } & Respiratory rate >90/min (infants $<12 \mathrm{mo}$ ) \\
\hline & Respiratory rate $>70 / \mathrm{min}$ (children $\geq 12 \mathrm{mo}$ ) \\
\hline & $\begin{array}{l}\mathrm{PaO}_{2}<40 \mathrm{~mm} \mathrm{Hg}(5.3 \mathrm{kPa}) \text { (in absence of } \\
\text { cyanotic heart disease) }\end{array}$ \\
\hline & $\mathrm{PaCO}_{2}>65 \mathrm{~mm} \mathrm{Hg}(8.6 \mathrm{kPa})$ \\
\hline & $\mathrm{PaO}_{2}$ to $\mathrm{FiO}_{2}$ ratio $<250 \mathrm{~mm} \mathrm{Hg}$ \\
\hline & $\begin{array}{l}\text { Mechanical ventilation ( }>24 \mathrm{~h} \text { if } \\
\text { postoperative) }\end{array}$ \\
\hline & $\begin{array}{l}\text { Tracheal intubation for airway obstruction or } \\
\text { acute respiratory failure }\end{array}$ \\
\hline \multirow[t]{4}{*}{ Neurologic } & Glascow Coma Scale $<5$ \\
\hline & Fixed, dilated pupils \\
\hline & Persistant (>20 min) intracranial pressure \\
\hline & $\begin{array}{l}>20 \mathrm{~mm} \mathrm{Hg} \text { or requiring therapeutic } \\
\text { intervention }\end{array}$ \\
\hline \multirow[t]{4}{*}{ Hematologic } & Hemoglobin $<5 \mathrm{~g} / \mathrm{dL}$ \\
\hline & White blood cell count $<3000$ cells $/ \mathrm{mm}^{3}$ \\
\hline & Platelets $<20,000 / \mathrm{mm}^{3}$ \\
\hline & $\begin{array}{l}\text { Disseminated intravascular coagulopathy (PT } \\
>20 \mathrm{~s} \text { or a PPT }>60 \mathrm{~s} \text { in presence of } \\
\text { positive FSP assay) }\end{array}$ \\
\hline \multirow[t]{2}{*}{ Renal } & Urea $>100 \mathrm{mg} / \mathrm{dL}(16.7 \mathrm{mmol} / \mathrm{L})$ \\
\hline & Serum creatinine $>2 \mathrm{mg} / \mathrm{dL}(175 \mu \mathrm{mol} / \mathrm{L})$ \\
\hline Gastrointestinal & Blood transfusion $>20 \mathrm{~mL} / \mathrm{kg}$ in $24 \mathrm{~h}$ because \\
\hline & of gastrointestinal hemorrhage \\
\hline \multirow[t]{4}{*}{ Hepatic } & Total bilirubin $>5 \mathrm{mg} / \mathrm{dL}(85 \mu \mathrm{mol} / \mathrm{L})$ and \\
\hline & aspartate aminotransferase more than twice \\
\hline & $\begin{array}{l}\text { normal value (without evidence of } \\
\text { hemolysis) }\end{array}$ \\
\hline & Hepatic encephalopathy > grade II \\
\hline
\end{tabular}

$\overline{F S P \text {, Fibrin split products; } P T \text {, prothrombin time; } a P T T \text {, activated partial }}$ thromboplastin time.

PFO or ASD was closed in $56(72 \%)$ and surgically restricted in 15 patients $(19 \%)$.

Intraoperative pressure and saturation measurements were performed before sternal closure. The median of the difference between the RV and main PA systolic pressures was $15 \mathrm{~mm} \mathrm{Hg}$ (range, $0-40 ; \mathrm{n}=63$ ), the mean RV to $\mathrm{LV}$ systolic pressure ratio was $0.48 \pm 0.11(\mathrm{n}=62)$, and the median main PA to RA percent oxygen saturation ratio was 1.01 (range, 0.88-1.16; $\mathrm{n}=37$ ). Intraoperative transesophageal echocardiography was performed after repair in 71 patients (91\%). Mild PI was found in 18 (25\%) and moderate in 13 patients (18\%). Pulmonary insufficiency was 
TABLE 2. Preoperative characteristics by age at repair

\begin{tabular}{|c|c|c|c|c|c|}
\hline Variable & $\begin{array}{c}<3 \text { Months } \\
(\mathrm{n}=12)\end{array}$ & $\begin{array}{c}3-<6 \text { Months } \\
(\mathrm{n}=20)\end{array}$ & $\begin{array}{c}6-<9 \text { Months } \\
(n=21)\end{array}$ & $\begin{array}{l}\geq 9 \text { Months } \\
(n=25)\end{array}$ & $P$ value \\
\hline Male/female & $7 / 5$ & $11 / 9$ & $10 / 11$ & $9 / 16$ & .14 \\
\hline Mean percent oxygen saturation in room air ( $\pm 1 \mathrm{SD}$ ) & $76 \pm 12$ & $86 \pm 14$ & $86 \pm 9$ & $85 \pm 10$ & .09 \\
\hline Cyanotic spells & 10 & 10 & 21 & 13 & .16 \\
\hline Coronary artery abnormalities & 1 & 5 & 2 & 3 & .69 \\
\hline Noncardiac abnormalities & 4 & 7 & 3 & 2 & .018 \\
\hline Malformation syndrome & 4 & 6 & 5 & 4 & .19 \\
\hline
\end{tabular}

trivial or unremarkable in the remaining $57 \%$. In 8 patients $(11 \%)$ the presence of a residual VSD was noted, but none required further repair. The median RV outflow tract gradient was $19 \mathrm{~mm} \mathrm{Hg}$ (range, 0-45, $\mathrm{n}=66$ ). All patients had modified ultrafiltration performed at the end of bypass.

\section{Postoperative ICU Data}

The median ICU length of stay was 2 days (range, 1-14), and the median mechanical ventilation time was 16.2 hours (range, 0-10.7 days), 1 patient being extubated in the operating room. In 2 patients, the sternum was left open at the end of the procedure and 4 additional patients had the sternum reopened for bleeding or because of myocardial edema ( 4 patients $<3$ months and $2>3$ months). Arrhythmias occurred in 19 patients (24\%), of whom 6 had junctional ectopic tachycardia and there was 1 patient with complete atrioventricular block. Temporary cardiac pacing was performed in 13 patients (17\%).

Chest radiograph abnormalities were noted in 57 patients (73\%); 43 with pleural effusion (75\%), and 38 with some degree of pulmonary atelectasis $(67 \%)$. Diaphragmatic paresis was noted in 1 patient $(1 \%)$. Reduced glucose levels were noted in 16 patients $(21 \%)$. None of the patients required renal replacement therapy. Six patients $(8 \%)$ were diagnosed with an infection, 3 with sepsis, 2 with mediastinitis, and 1 with a urinary tract infection.

Using the MODS criteria, as defined as dysfunction of 2 or more organ systems, which extended beyond 48 hours, was noted in 9 patients. Of these, 1 patient had dysfunction of 2 organs and 8 patients had dysfunction of 3 or 4 organs. All went on to make a full recovery. Intravenous dopamine was used in 65 patients $(83 \%)$ after the first hour, in 31 patients (49\%) after 24 hours, and in 12 patients (41\%) after 48 hours ICU admission. At the same time points, intravenous amrinone or milrinone was used in 7 (9\%), 15 (24\%), and 12 patients $(41 \%)$, respectively. Intravenous epinephrine was used in $2(3 \%), 5(8 \%)$, and 5 patients $(17 \%)$ at these time points. Intravenous sodium nitroprusside was used in 62 patients (79\%) after 1 hour, to 25 patients (40\%) after 24 hours, and to 12 (41\%) after 48 hours ICU admission.

\section{Death or Reintervention Within 30 Days}

There were no deaths during the postoperative hospital stay. However, 1 patient was known to have died following discharge from the hospital, 21 days after repair. The cause of death was cardiac tamponade associated with noninfective pericarditis and an effusion (postpericardiotomy syndrome). No patient required reintervention within 30 days of operation. Five patients underwent cardiac catheterization with stenting or dilatation of the RV outflow tract or pulmonary arteries, all more than 6 months after surgery.

\section{Relationship of Perioperative Characteristics to Age at Repair}

Differences between age groups regarding preoperative characteristics are given in Table 2. There were no agerelated differences regarding any cardiac anomalies. However, younger patients were significantly more likely to have extracardiac anomalies.

The relationships between operative characteristics and age groups are shown in Table 3. There were no significant differences between age groups regarding operative technique. There were no significant age-related trends in intraoperative direct hemodynamic measurements or in immediate echocardiographic variables.

Trends related to age groups in postoperative management and outcomes are shown in Table 4. Patients in the youngest age group had significantly higher scores related to organ system dysfunction. There were no significant age-related differences regarding arrhythmias. Fluid balance measurements in the first 2 postoperative days showed no significant trends over age groups regarding urine output or chest tube losses, but patients less than 3 months of age required significantly more fluid with a tendency towards a more positive fluid balance. Both duration of mechanical ventilation and duration of ICU stay were significantly related to age at repair.

\section{Factors Associated with Duration of Mechanical Ventilation}

Significant independent factors associated with a longer duration of mechanical ventilation are shown in Table 5, 
TABLE 3. Operative characteristics by age at repair

\begin{tabular}{|c|c|c|c|c|c|}
\hline Variable & $\begin{array}{c}<3 \text { months } \\
\text { (n=12) }\end{array}$ & $\begin{array}{c}3 \leq 6 \text { months } \\
(n=20)\end{array}$ & $\begin{array}{c}6 \leq 9 \text { months } \\
(n=21)\end{array}$ & $\begin{array}{l}\geq 9 \text { months } \\
(n=25)\end{array}$ & $P$ value \\
\hline Use of a transannular patch with a monocusp valve & 2 & 2 & 4 & 5 & .54 \\
\hline Use of only a transannular patch & 4 & 4 & 2 & 5 & .37 \\
\hline PA arterioplasty & 12 & 16 & 19 & 25 & .32 \\
\hline Median difference between RV and main PA & $10(4-20)$ & $14(5-40)$ & $15(2-31)$ & $16(0-30)$ & .50 \\
\hline systolic pressures (mm Hg; range) & $\mathrm{n}=11$ & $\mathrm{n}=15$ & $\mathrm{n}=15$ & $\mathrm{n}=22$ & \\
\hline Mean RV to LV systolic pressure ratio ( $\pm 1 \mathrm{SD}$ ) & $\begin{array}{c}0.47 \pm 0.10 \\
n=11\end{array}$ & $\begin{array}{c}0.44 \pm 0.13 \\
n=15\end{array}$ & $\begin{array}{c}0.47 \pm 0.09 \\
n=14\end{array}$ & $\begin{array}{c}0.52 \pm 0.12 \\
\mathrm{n}=22\end{array}$ & .32 \\
\hline
\end{tabular}

$L V$, Left ventricle; $P A$, pulmonary artery; $R V$, right ventricle; $S D$, standard deviation.

TABLE 4. Postoperative characteristics by age at repair

\begin{tabular}{|c|c|c|c|c|c|}
\hline Variable & $\begin{array}{c}<3 \text { months } \\
(n=12)\end{array}$ & $\begin{array}{c}3 \leq 6 \text { months } \\
(n=20)\end{array}$ & $\begin{array}{c}6 \leq 9 \text { months } \\
(n=21)\end{array}$ & $\begin{array}{c}\geq 9 \text { months } \\
(n=25)\end{array}$ & $P$ value \\
\hline Median length of stay (d) in the ICU (range) & $5.5(1-14)$ & $2(1-7)$ & $2(1-10)$ & $1(1-7)$ & .002 \\
\hline $\begin{array}{l}\text { Median time (h) on mechanical ventilation } \\
\text { (range) }\end{array}$ & $100(9-258)$ & $18(5-143)$ & $13(5-230)$ & $12(<1-49)$ & $<.0001$ \\
\hline Use of 2 or more intravenous inotropic agents & 8 & 6 & 3 & 1 & $<.0001$ \\
\hline Use of any intravenous vasodilatory agent & 12 & 18 & 20 & 20 & .085 \\
\hline \multicolumn{6}{|l|}{ Organ system dysfunction } \\
\hline None & 0 & 3 & 1 & 5 & $<.001$ \\
\hline 1 & 0 & 13 & 15 & 17 & \\
\hline 2 & 4 & 2 & 4 & 1 & \\
\hline 3 & 4 & 2 & 0 & 2 & \\
\hline 4 & 4 & 0 & 1 & 0 & \\
\hline Occurrence of arrhythmias & 4 & 5 & 3 & 5 & .38 \\
\hline Occurrence of junctional ectopic tachycardia & 1 & 2 & 1 & 2 & .84 \\
\hline $\begin{array}{l}\text { Mean total of fluid input during the first } 48 \mathrm{~h} \\
\text { post-ICU admission (mL/kg per } h ; \pm 1 \text { SD) }\end{array}$ & $7.2 \pm 3.3$ & $4.7 \pm 2.9$ & $3.8 \pm 1.0$ & $4.4 \pm 2.1$ & .002 \\
\hline $\begin{array}{l}\text { Mean difference between fluid input and fluid } \\
\text { output during the first } 48 \mathrm{~h} \text { post-ICU } \\
\text { admission (mL/kg per } \mathrm{h} ; \pm 1 \mathrm{SD} \text { ) }\end{array}$ & $2.0 \pm 1.2$ & $1.4 \pm 1.0$ & $1.1 \pm 0.9$ & $1.2 \pm 1.0$ & .084 \\
\hline
\end{tabular}

ICU, Intensive care unit; $S D$, standard deviation.

and include the presence of a noncardiac malformation syndrome or coronary artery anomaly, occurrence of preoperative cyanotic spells, age at repair less than 3 months, and the postoperative use of 2 or more intravenous inotropic agents or any vasodilatory agent. After controlling for these variables, no other pre-, peri-, or postoperative variable could be entered into the model.

\section{Factors Associated with Length of Stay in the ICU}

Kaplan-Meier estimates of time-related discharge from the ICU were plotted and are shown in Figure 1. The majority of patients had a length of stay of 1 or 2 days. Significant independent factors associated with a prolonged time to ICU discharge are shown in Table 5, and include the presence of a noncardiac malformation syndrome, longer duration of cardiopulmonary bypass, and the postoperative use of 2 or more intravenous inotropic agents. After controlling for these variables, no other pre-, peri-, or postoperative variable, including younger age at repair, could be entered into the model. Alternatively, given the non-normal distribution of length of ICU stay, the variable was categorized as 1 or 2 days versus 3 or more days. Significant independent factors associated with an ICU stay of more than 2 days are shown in Table 5, and include age at repair less than 3 months and the postoperative use of 2 or more intravenous inotropic agents. After controlling for these variables, no other pre-, peri-, or postoperative variable could be entered into the model. Age more than 3 months at repair was not a risk factor for increased ICU stay.

\section{Discussion}

The change in management algorithm for TOF from palliation with later repair to early primary repair prompted this review. The outcome in the present study is comparable to other reported series of early repairs of patients with tetralogy. 2,5,6,8,9,12,14 Although we anticipated that the mortality 
TABLE 5. Independent factors associated with duration of mechanical ventilation, ${ }^{*}$ time to discharge from intensive care unit, $\uparrow$ and length of stay in the intensive care unit 2 days $\neq$

\begin{tabular}{|c|c|c|c|c|}
\hline Variable & $\beta$ Coefficient§ & $P$ value & $\begin{array}{l}\text { Adjusted } \\
\text { risk ratio }\end{array}$ & $95 \% \mathrm{Cl}$ \\
\hline Intercept & $5.616(0.404)$ & & & \\
\hline Malformation syndrome & $0.502(0.236)$ & .037 & & \\
\hline Coronary artery anomaly & $0.587(0.332)$ & .082 & & \\
\hline Preoperative hypercyanotic episodes & $0.489(0.220)$ & .029 & & \\
\hline Age at repair $<3$ months & $0.857(0.325)$ & .01 & & \\
\hline 2 or more inotropic agents & $1.039(0.310)$ & .002 & & \\
\hline Intravenous vasodilatory agents & $1.109(0.348)$ & .002 & & \\
\hline \multicolumn{5}{|l|}{ Independent factors associated with time to discharge from ICU† } \\
\hline Malformation syndrome & $0.631(0.286)$ & .028 & 1.88 & $1.07-3.29$ \\
\hline Longer cardiopulmonary bypass time (per 10 -min increment) & $0.081(0.029)$ & .005 & 1.08 & $1.02-1.15$ \\
\hline 2 or more intravenous inotropic agents & $1.722(0.439)$ & $<.0001$ & 5.60 & $2.37-13.2$ \\
\hline \multicolumn{5}{|l|}{$\begin{array}{l}\text { Independent factors associated with length of stay in the ICU > } \\
2 \text { days } \ddagger\end{array}$} \\
\hline Intercept & $-2.153(0.432)$ & & & \\
\hline Age at repair $<3$ months & $2.325(1.008)$ & .022 & 10.2 & 1.42-73.7 \\
\hline Two or more inotropic agents & $3.650(0.875)$ & $<.0001$ & 38.5 & $6.92-214$ \\
\hline
\end{tabular}

$\mathrm{Cl}$, Confidence interval.

*From general linear regression analysis; $R^{2}=0.57, P<.0001 ; P<.15$ was used for both variable selection and entry into the model building; time of mechanical ventilation in hours was analyzed after natural logarithmic transformation.

†From Cox's proportionate hazard modeling.

†From multiple logistic regression; Hosmer-Lemmeshow goodness of fit, $P=.90$.

$\S$ Numbers in parentheses are the standard error of the estimate.

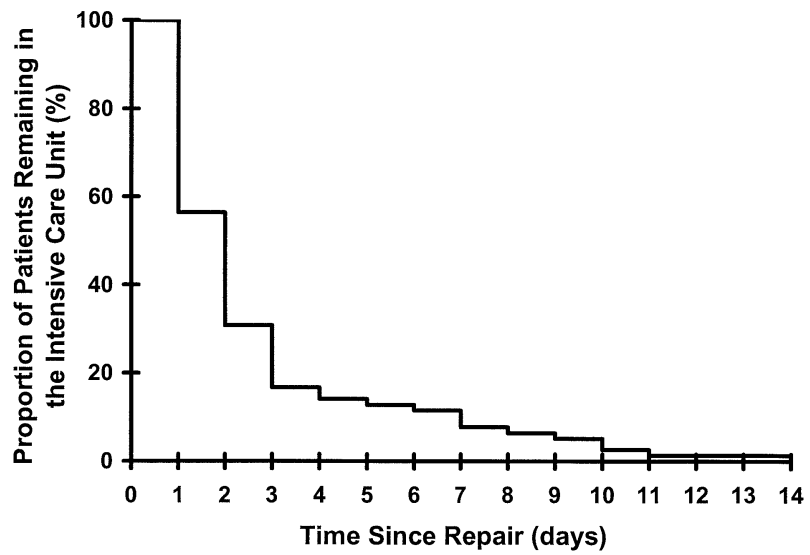

Figure 1. Kaplan-Meier graph showing time to ICU discharge.

would be low despite this change in surgical management we were concerned that there might be a clinically important increase in early postoperative morbidity associated with the increased number of repairs in the first 3 months of life. This might be reflected in an increased duration of ventilator and hemodynamic support and a higher incidence of organ system failures, which would impact on mortality. However, this concern was not realized. Younger age at repair was associated with a longer cardiopulmonary bypass time, an increased level of postoperative support (duration of ventilation, intravenous inotropes), and although this resulted in increased length of ICU stay, there was no long-term morbidity. The use of the MODS score, a commonly used descriptor in critical care to assess severity of illness, provides important supportive data. Given that most, if not all, patients who undergo repair of congenital heart disease will develop cardiorespiratory failure it is worth noting that only $9(12 \%)$ had more than 2 organ system failures that extended beyond 48 hours after repair, all of which were self-limiting. No patient required renal replacement therapy. Very few outcome studies have applied the MODS score in the setting of congenital heart surgery. Seghaye and colleagues ${ }^{22}$ retrospectively studied the incidence of multi-organ dysfunction in a cohort of children who had undergone cardiac surgery using an arbitrarily adapted score and found an incidence of $3.5 \%$. Five of the 6 patients with TOF repair in their series who developed MODS died and 1 had a poor neurological outcome.

The publication of our previous outcome study of tetralogy patients, ${ }^{20}$ which also focused on the immediate morbidity associated with repair at a somewhat older age, allows us to make some interesting comparisons (Table 6). In our previously reported series, $24 \%$ of patients had a prior shunt and there were $6(7 \%)$ deaths within the first 48 hours of surgery. The median age at repair is lower in the current series ( 8 vs 13 months) and the proportion of patients less than 6 months of age at repair is higher (41\% vs $10 \%$ ). In our current series, $70 \%$ of patients were discharged from ICU within 2 days compared with $20 \%$ previously. The 
TABLE 6. Differences in outcomes between the study period from 1987 to 1994 and the study period from 1997 to 1999

\begin{tabular}{lcc}
\hline & Study period 1997-1999 & Study period 1987-1994 \\
\hline Number of patients & 78 & 89 \\
$0-6$ months & $32(41 \%)$ & $9(10 \%)$ \\
6-8 months & $21(27 \%)$ & $10(11 \%)$ \\
$>9$ months & $25(32 \%)$ & $70(79 \%)$ \\
Median age at surgery (range) & 8 months $(36$ days-18.5 months) & 13 months $(15$ days-17.9 months) \\
Median length of stay (d) in the ICU (range) & $2(1-14)$ & $5(1-40)$ \\
Median time on mechanical ventilation (range) & 16 hours (0 hours-11 days) & 74 hours (11 hours-30 days) \\
Occurrence of junctional ectopic tachycardia & $6(8 \%)$ & $18(20 \%)$ \\
Occurrence of diaphragmatic palsy & $1(1 \%)$ & $4(4 \%)$ \\
Occurrence of death under 30 days postoperatively & $1(1 \%)$ & $6(7 \%)$ \\
Occurrence of death under 48 h & 0 & $6(7 \%)$ \\
\hline
\end{tabular}

median duration of ventilation was 16 hours compared with 74 hours in 1987 to 1994 . This may be accounted for partially by a change in management philosophy to one of early extubation, which has evolved based on studies showing the adverse effect of positive pressure ventilation in patients with tetralogy and restrictive RV physiology. ${ }^{23,24}$ The incidence of JET, one of the most hemodynamically significant arrhythmias, has previously been reported to be increased with younger age at repair. ${ }^{9,25} \mathrm{We}$ did not find this and, more particularly, the occurrence rate $(8 \%)$ in our recent series is less than we reported previously (20\%). Despite reports of more frequent use of outflow tract patches in young infants, ${ }^{13}$ there is a trend at our institution towards a decreasing use of a transannular patch with more frequent sparing of the pulmonary valve and more frequent use of PA arterioplasty. ${ }^{15,20}$

\section{Conclusions and Study Limitations}

This retrospective review demonstrates that early repair of TOF is associated with excellent survival and a low incidence of postoperative morbidity and lends support to the policy of definitive repair rather than palliation. However, it does not address the issue of repairs of lesion in neonates $(<28$ days of age) as there were no patients in this age group. Nor does it address the issue of whether early repair leads to functionally improved long-term outcome and was only designed to address the issue of immediate postoperative morbidity. While many factors, both operative and postoperative, may influence outcome in addition to those analyzed, and some caution needs to be exercised in comparing results over an extended period, nevertheless the trend to improvement in outcome over the past decade despite younger age at repair appears to justify this approach.

\section{References}

1. Caspi J, Zalstein E, Zucker N, Applebaum A, Harrison LH Jr, Munfakh NA, et al. Surgical management of tetralogy of Fallot in the first year of life. Ann Thorac Surg. 1999;68:1344-9.
2. Castaneda AR, Freed MD, Williams RG, Norwood WI. Repair of tetralogy of Fallot in infancy. Early and late results. $J$ Thorac Cardiovasc Surg. 1977;74:372-81.

3. Castaneda AR, Mayer JE Jr, Jonas RA, Lock JE, Wessel DL, Hickey PR. The neonate with critical congenital heart disease: repair-a surgical challenge. J Thorac Cardiovasc Surg. 1989;98(5 Pt 2):869-75.

4. Di Donato RM, Jonas RA, Lang P, Rome JJ, Mayer JE Jr, Castaneda AR. Neonatal repair of tetralogy of Fallot with and without pulmonary atresia. J Thorac Cardiovasc Surg. 1991;101:126-37.

5. Gustafson RA, Murray GF, Warden HE, Hill RC, Rozar GE Jr. Early primary repair of tetralogy of Fallot. Ann Thorac Surg. 1988;45:23541.

6. Hennein HA, Mosca RS, Urcelay G, Crowley DC, Bove EL. Intermediate results after complete repair of tetralogy of Fallot in neonates. J Thorac Cardiovasc Surg. 1995;109:332-43.

7. Karl TR, Sano S, Pornviliwan S, Mee RB. Tetralogy of Fallot: favorable outcome of nonneonatal transatrial, transpulmonary repair. Ann Thorac Surg. 1992;54:903-7.

8. McElhinney DB, Reddy VM, Hanley FL. Tetralogy of Fallot with major aortopulmonary collaterals: early total repair. Pediatr Cardiol. 1998;19:289-96.

9. Pigula FA, Khalil PN, Mayer JE, del Nido PJ, Jonas RA. Repair of tetralogy of Fallot in neonates and young infants. Circulation. 1999; 100(Suppl 19):II157-61.

10. Reddy VM, Liddicoat JR, McElhinney DB, Brook MM, Stanger P, Hanley FL. Routine primary repair of tetralogy of Fallot in neonates and infants less than three months of age. Ann Thorac Surg. 1995; 60(Suppl 6):S592-6.

11. Sousa Uva M, Lacour-Gayet F, Komiya T, Serraf A, Bruniaux J, Touchot A, et al. Surgery for tetralogy of Fallot at less than six months of age. J Thorac Cardiovasc Surg. 1994;107:1291-300.

12. Touati GD, Vouhe PR, Amodeo A, Pouard P, Mauriat P, Leca F, et al. Primary repair of tetralogy of Fallot in infancy. $J$ Thorac Cardiovasc Surg. 1990;99:396-403.

13. Knott-Craig CJ, Elkins RC, Lane MM, Holz J, McCue C, Ward KE. A 26-year experience with surgical management of tetralogy of Fallot: risk analysis for mortality or late reintervention. Ann Thorac Surg. 1998;66:506-11.

14. Parry AJ, McElhinnery DB, Kung GC, Reddy VM, Brook MM, Hanley FL. Elective primary repair of a cyanotic tetralogy of Fallot in early infancy: overall outcome and impact on the pulmonary valve. J Am Coll Cardiol. 2000;36:2279-83.

15. Van Arsdell GS, Maharaj GS, Tom J, Rao VK, Coles JG, Freedom RM, et al. What is the optimal age for repair of tetralogy of Fallot? Circulation. 2000;102(19 Suppl 3):III123-9.

16. Gatzoulis MA, Balaji S, Webber SA, Siu SC, Hokanson JS, Poile C, et al. Risk factors for arrhythmia and sudden cardiac death late after repair of tetralogy of Fallot: a multicentre study. Lancet. 2000;356(9234):975-81.

17. Gladman G, McCrindle BW, Williams WG, Freedom RM, Benson 
LN. The modified Blalock-Taussig shunt: clinical impact and morbidity in Fallot's tetralogy in the current era. J Thorac Cardiovasc Surg. 1997; 114:25-30

18. Sousa Uva M, Chardigny C, Galetti L, Lacour-Gayet F, Roussin R, Serraf A, et al. Surgery for tetralogy of Fallot at less than six months of age. Is palliation "old-fashioned" Eur J Cardiothorac Surg. 1995; 9:453-9.

19. Vobecky SJ, Williams WG, Trusler GA, Coles JG, Rebeyka IM, Smallhorn J, et al. Survival analysis of infants under age 18 months presenting with tetralogy of Fallot. Ann Thorac Surg. 1993;56:944-50.

20. Dyamenahalli U, McCrindle BW, Barker GA, Williams WG, Freedom RM, Bohn DJ. Influence of perioperative factors on outcomes in children younger than 18 months after repair of tetralogy of Fallot. Ann Thorac Surg. 2000;69:1236-42.

21. Wilkinson JD, Pollack MM, Glass NL, Kanter RK, Katz RW, Stein- hart CM. Mortality associated with multiple organ system failure and sepsis in pediatric intensive care unit. J Pediatr. 1987;111:324-8.

22. Seghaye MC, Engelhardt W, Grabitz RG, Faymonville ME, Hornchen H, Messmer BJ, et al. Multiple system organ failure after open heart surgery in infants and children. Thorac Cardiovasc Surg. 1993;41:49-53.

23. Shekerdemian LS, Bush A, Shore DF, Lincoln C, Redington AN. Cardiorespiratory responses to negative pressure ventilation after tetralogy of fallot repair: a hemodynamic tool for patients with a lowoutput state. J Am Coll Cardiol. 1999;33:549-55.

24. Shekerdemian LS, Shore DF, Lincoln C, Bush A, Redington AN. Negative-pressure ventilation improves cardiac output after right heart surgery. Circulation. 1996;94(9 Suppl):II49-55.

25. Rouillard KP, Hanley FL, Dorostkar PC. Early repair of tetralogy of Fallot is associated with a higher incidence of postoperative junctional ectopic tachycardia. [abstract]. J Am Coll Cardiol. 1998:355.

Access to The Journal of Thoracic and Cardiovascular Surgery Online is reserved for print subscribers!

Full-text access to The Journal of Thoracic and Cardiovascular Surgery Online is available for all print subscribers. To activate your individual online subscription, please visit The Journal of Thoracic and Cardiovascular Surgery Online, point your browser to http://www.mosby.com/jtcvs, follow the prompts to activate your online access, and follow the instructions. To activate your account, you will need your subscriber account number, which you can find on your mailing label (note: the number of digits in your subscriber account number varies from 6 to 10). See the example below in which the subscriber account number has been circled:

\section{Sample mailing label}

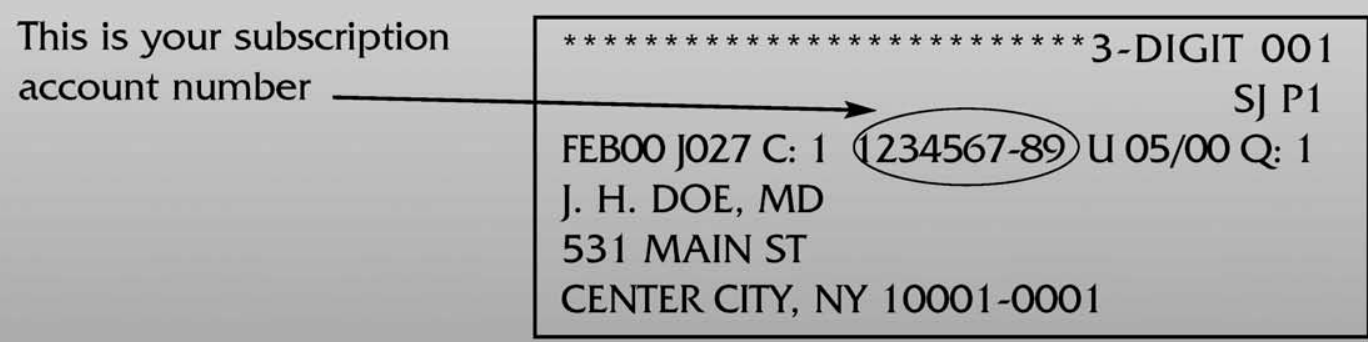

Personal subscriptions to The Journal of Thoracic and Cardiovascular Surgery Online are for individual use only and may not be transferred. Use of The Journal of Thoracic and Cardiovascular Surgery Online is subject to agreement to the terms and conditions as indicated online. 